Bangladesh J. Plant Taxon. 20(2): 129-134, 2013 (December)

(C) 2013 Bangladesh Association of Plant Taxonomists

\title{
PRIMULINA CRASSIRHIZOMA SP. NOV. (GESNERIACEAE) FROM A LIMESTONE AREA ALONG THE BOUNDARY OF SINO-VIETNAM
}

\author{
Bo Zhao, Xin Hong ${ }^{1}$, Shi-Lian Huang and Fang Wen ${ }^{3,4}$ \\ Guilin Botanic Garden, Guangxi Institute of Botany, Guangxi Zhuang Autonomous Region \\ and the Chinese Academy of Sciences, CN-541006, Guilin, China.
}

Keywords: Gesneriaceae; New species; Primulina crassirhizoma; Limestone flora; China.

\begin{abstract}
Primulina crassirhizoma F. Wen, Bo Zhao \& Xin Hong, a new species from a limestone area along the boundary of Sino-Vietnam, is described and illustrated. It is similar to $P$. linearifolia and $P$. longgangensis in leaf and flower shape, but can be distinguished by extremely strong rhozime, with conspicuous internodes, leaf blade adaxial surface nitid, sparsely appressed strigose, lateral veins $6-8$ on each side of midrib, calyx narrowly triangular to narrowly ovate, corolla pale purple to bluish purple, c. $3.5 \mathrm{~cm}$ long, tube nearly tubular, adaxial lip c. $6 \mathrm{~mm}$, abaxial lip 8-9 mm, glabrous anthers and staminodes 3 .
\end{abstract}

\section{Introduction}

The distribution and differentiation centre of Primulina Hance (Gesneriaceae) located to South and South-west China and North Vietnam (Wei et al., 2010), and many species and varieties of this genus are usually endemic to China, especially in the limestone areas of Guangxi Zhuang Autonomous Region. Very recently some taxa of Primulina Hance have been newly described from Guangxi, China, viz. P. purpurea Fang Wen, Bo Zhao \& Y.G Wei (Wen et al., 2012a), P. hochiensis var. rosulata F. Wen \& Y.G. Wei (Wen et al., 2012b) and P. fengshanensis Fang Wen \& Yue Wang (Wen et al., 2012c).

In 2004, Shi-Liang Mo, a tourist first collected some "Primulina"-like plants from Longbang town, Jingxi County, Guangxi, China. Later on, we found this particular unknown species near the top of limestone hills along the boundary of Sino-Vietnam in 2005. After five years, Prof. Hai He and Prof. Li-Bing Zhang collected many specimens of this particular species with flowers from Pingan town, Jingxi County in 2010. Although this unknown taxon looks like Primulina linearifolia (W.T. Wang) Y.Z. Wang (Wang and Pan, 1982; Wang et al., 2011) and P. longgangensis (W.T. Wang) Y.Z. Wang (Wang and Huang, 1982; Wang et al., 2011), we could easily distinguished three species by the characters of leaves and flowers. After consultation of relevant literatures (Wang et al., 1990, 1998, 2011; Li and Wang, 2004; Wei et al., 2010; Weber et al., 2011; Xu et al., 2012), and examination of the specimens deposited in different herbaria (ANU, BJFU, CDBI, HN, IBK, IBSC, KUN, PE, VMN, CTC, MO, CDBI), we concluded it as a new species, Primulina crassirhizoma sp. nov. The new species is described and illustrated here.

${ }^{1}$ College of Life Sciences, Anhui Normal University, CN-241000, Wuhu, China.

${ }^{2}$ College of Life Sciences, Guangxi Normal University, Guilin CN-541004, China

${ }^{3}$ Guangxi Institute of Botany, Guangxi Zhuang Autonomous Region and the Chinese Academy of Sciences, CN-541006 Guilin, China.

${ }^{4}$ Corresponding author. Email: wenfang760608@139.com 
Primulina crassirhizoma F. Wen, Bo Zhao \& Xin Hong, sp. nov.

(Fig. 1, Fig. 2 A-F).

Diagnosis: Haec species nova similis Primulina linearifoliae et $P$. longgangensis, sed differ rhizomate incrassato et robusto, conspicue internodiis, laminis supra nitidis, sparse appresso strigosis, lateralis nervis 6-8, calyce anguste triangulo et anguste ovato, corolla pallido purpurata usque caesie purpurata, ca. $3.5 \mathrm{~cm}$ longa, tubis fere tubulari, labio postico ca. $6 \mathrm{~mm}$ longo, eo antice 8-9 mm longo, filamentis ca. 0.9-1.1 cm longis, antheris glabris, staminodiis 3.

Type: CHINA, Guangxi Zhuangzu Autonomous Region: Jingxi County, Longbang Township, near Tunhong village, growing in the crevices of rock, under evergreen broad-leaved forest or bamboo bushes, near to the top of limestone hills, $22^{\circ} 52^{\prime} 37.78^{\prime \prime} \mathrm{N}, 106^{\circ} 21^{\prime} 35.80^{\prime \prime} \mathrm{E}, 781.5 \mathrm{~m}, 26$ November 2006, FANG WEN \& Xin Hong 0169 (Holotype: IBK; Isotype: ANU).

Perennial, acaulescent. Rhizome subterete, erect or ascending, single, in very thick and strong trunks, woody, brown, with conspicuous internodes, up to $30 \mathrm{~cm}$ long, 1.0-1.5 (-4) $\mathrm{cm}$ in diam. Leaves 6-16 or more, congested at the apex of rhizome, opposite on upper half of rhizome; petiole $2-5 \times 4.5-6.0 \mathrm{~cm}$; leaf blade thickly coriaceous, narrowly elliptic, oblanceolate to oblong, 8-12 $\times$ 2.2-3.0 cm, adaxial surface nitid, sparsely appressed strigose, abaxial sparsely strigose, extremely short brownish pubescent along veins, apex acute, base attenuate to slightly obliquely cuneate, margin with inconspicuous obtusely dentate from the middle to the apex, revolute, lateral veins 68 on each side of midrib, slightly impressed adaxially, prominent ribs abaxially. Cymes 2-6 or more on one stem, axillary, (1-) 3-16-flowered; peduncle 9-16 cm long, 0.1-0.2 cm in diam., densely erect, dark purple glandular puberulent; bracts linear-lanceolate to lanceolate-ovate, 5-8 $\mathrm{mm}$ long, 2.0-2.5 mm in diam., puberulous outside, glabrous inside; pedicel $0.6-2.2 \mathrm{~cm}$ long, c. $0.1 \mathrm{~cm}$ in diam., glandular-pubescent. Calyx 5-partite to the base, lobes narrowly triangular to narrowly ovate, $2.6-3.5 \times 1.1-1.4 \mathrm{~mm}$, brownish red, pubescent abaxially, glabrous adaxially, acute, entire. Corolla c. $3.5 \mathrm{~cm}$ long, c. $0.9 \mathrm{~cm}$ in diam. at the orifice, c. $0.4 \mathrm{~mm}$ in diam. at the base, pale purple to bluish-purple, outside glandular pubescent, inside glabrous; tube nearly tubular, c. $2 \mathrm{~cm}$ long; limb distinctly 2-lipped, upper lip 2-lobed near base, lobes ovate-rounded to rounded, c. $6 \times 8 \mathrm{~mm}$, retroflexed, lower lip 3-lobed to near two-third, central lobe orbicular, lateral ones obliquely ovate, $8-9 \times 9-10 \mathrm{~mm}$. Stamens 2 , adnate $1.1-1.3 \mathrm{~cm}$ above the corolla base; filaments 0.9-1.1 cm long, upper parts geniculate, scattered glandular pubescent; anthers fused by their entire adaxial surfaces, elliptic or reniform, c. $2 \mathrm{~mm}$ long, glabrous; staminodes 3, lateral ones c. $2.6 \mathrm{~mm}$ long, adnate up to c. $0.8 \mathrm{~cm}$ above the corolla base, apex inflated, scattered glandular pubescent, middle one adnate, up to c. $0.6 \mathrm{~cm}$ above the corolla base, very small, capitate, c. $0.3 \mathrm{~mm}$ long, glabrous. Disc 1.5-2.0 mm long, margin repand, glabrous. Pistil c. $2 \mathrm{~cm}$ long; ovary linear, c. $1.5 \times 0.2 \mathrm{~cm}$, densely puberulent with both glandular and eglandular hairs; style c. $0.5 \mathrm{~cm}$ long, c. $1 \mathrm{~mm}$ in diam., glandular-puberulent; stigma obtrapeziform, c. $0.4 \mathrm{~cm}$ long, 2-lobed to middle. Capsule straight, $4.0-5.5 \mathrm{~cm}$ long, c. $4 \mathrm{~mm}$ in diam., glandular-pubescent and sparsely pilose.

Phenology: It flowers from November to early December.

Ecology: At least five populations have been found for the new species around the border of China (Tunhong village of Longbang town, Jingxi County, Guangxi) (Fig. 3). Besides, some plants of this new species were introduced and cultivated in Royal Botanic Gardens, Kew in past ten years from Vietnam, but they are lack of specific information of Vietnamese locality, and known only from Cao Bằng province of North Vietnam. All known populations in China are growing at the crevices in evergreen limestone broad-leaved forest or bamboo-bushes near the peak of limestone hills.

Etymology: The specific epithet is derived from its extremely thick and robust rhizome. 


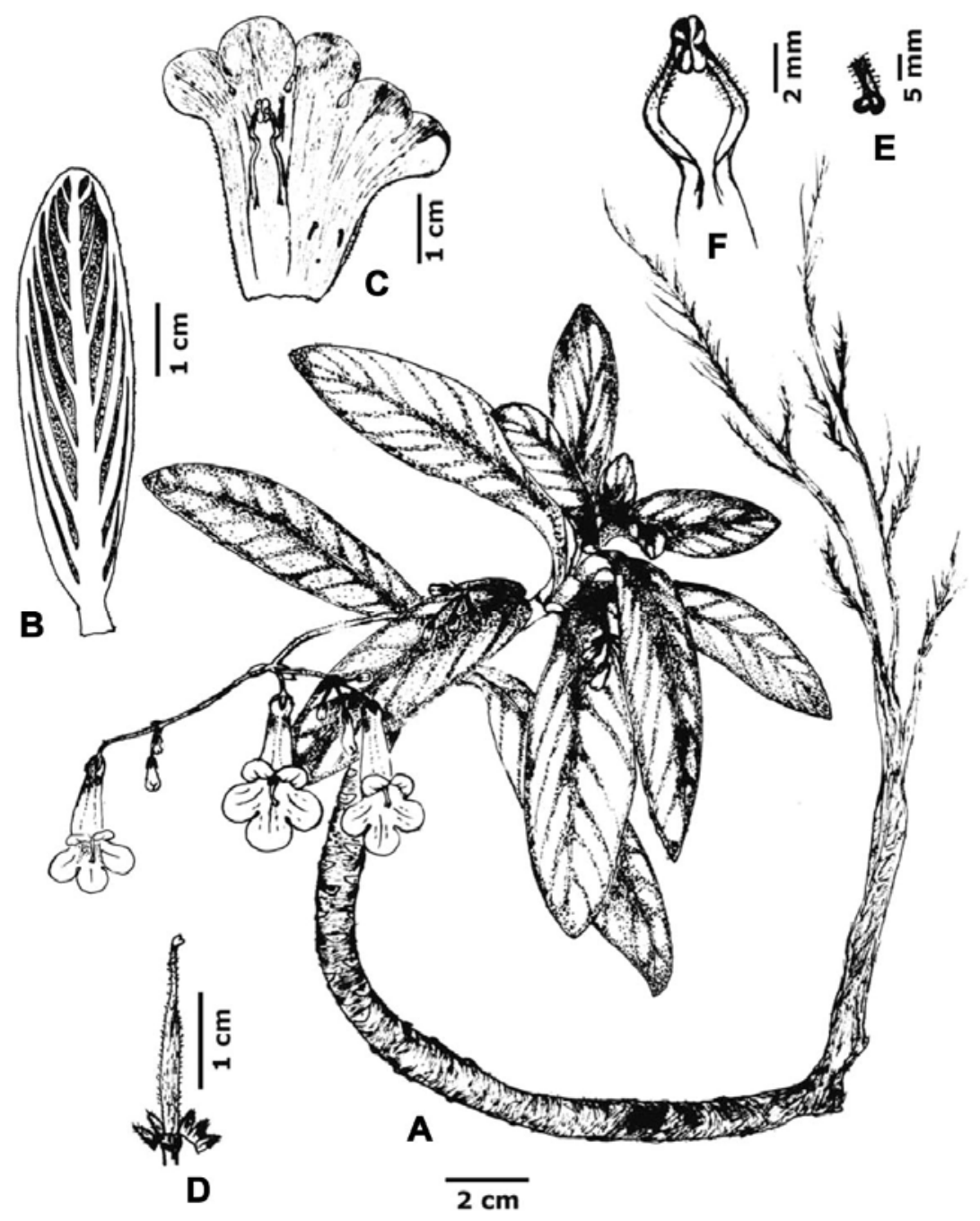

Fig. 1 A-F. Primulina crassirhizoma F. Wen, Bo Zhao \& Xin Hong sp. nov. A) Habit; B) Back of leaf blade; C) Corolla, dissected to show stamens and staminodes; D) Pistil, dissected calyx lobes and disc; E) Stigma; F) Stamens and anthers. (All from the type, Fang Wen and Xin Hong 0169, IBK).

Note: Primulina crassirhizoma is morphologically similar to P. linearifolia (W.T. Wang) Y.Z. Wang and P. longgangensis (W.T. Wang) Y.Z. Wang, but it differs from these species in having thick and strong rhizome, with conspicuous internodes; adaxial surface of leaf blade nitid, sparsely appressed strigose; lateral veins 6-8 on each side of midrib; calyx narrowly triangular to narrowly ovate; corolla pale purple to bluish-purple, c. $3.5 \mathrm{~cm}$ long; tube nearly tubular, adaxial lip c. $6 \mathrm{~mm}$; abaxial lip c. 8-9 mm; filaments ca. 0.9-1.1 cm long; anthers glabrous; staminodes 3. The differences of three relatives are shown in Table 1 and Fig. 2. 


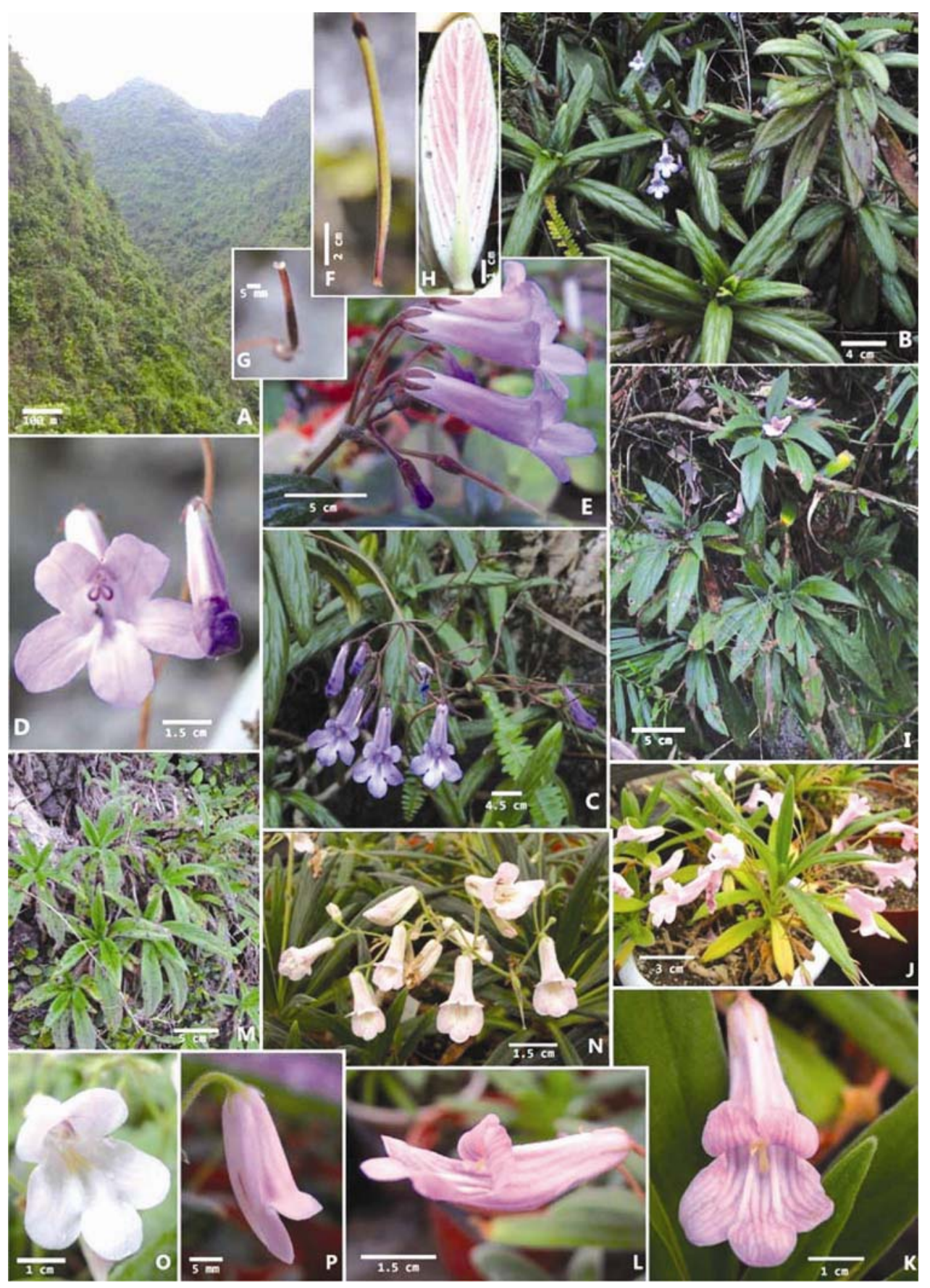

Fig. 2 A-F. Primulina crassirhizoma F. Wen, Bo Zhao \& Xin Hong sp. nov. A) Habitat; B) Habit; C) Cymes and flowers; D) Front view of flower and bud; E) Lateral view of flowers and calyx lobes; F) Pistil; G. Stigma; H. Back of leaf blade; I-L. P. longgangensis I) Habit; J) Cymes and flowers; K) Front view of flower; L) Lateral view of flower and calyx lobes; M-P. P. linearifolia M) Habit; N) Cymes and flowers; O) Front view of flower; P) Lateral view of flower and calyx lobes. 
Table 1. Diagnostic morphological characters of Primulina crassirhizoma, $P$. longgangensis and $P$. linearifolia.

\begin{tabular}{|c|c|c|c|}
\hline Characters & P. crassirhizoma & P. longgangensis & P. linearifolia \\
\hline Rhizome & $\begin{array}{l}1.0-1.5(-4) \mathrm{cm} \text { in diam., } \\
\text { internodes conspicuous }\end{array}$ & $\begin{array}{l}0.4-0.7 \mathrm{~cm} \text { in diam., } \\
\text { internodes conspicuous }\end{array}$ & $\begin{array}{l}0.4-1.0 \mathrm{~cm}, \text { internodes } \\
\text { inconspicuous }\end{array}$ \\
\hline $\begin{array}{l}\text { Indumentum of } \\
\text { leaf blade }\end{array}$ & $\begin{array}{l}\text { Adaxial surface nitid, } \\
\text { Sparsely appressed strigose }\end{array}$ & $\begin{array}{l}\text { Densely appressed } \\
\text { puberulent and pilose }\end{array}$ & Appressed pubescent \\
\hline Lateral veins & 6-8 on each side of midrib & $3-6$ on each side of midrib & 4 or 5 on each side of midrib \\
\hline Calyx & $\begin{array}{l}\text { Narrowly triangular to } \\
\text { narrowly ovate, } 2.6-2.8 \times 0.3- \\
0.5 \mathrm{~mm}\end{array}$ & $\begin{array}{l}\text { Lanceolate-linear, } 5-8 \times \\
0.9-1.5 \mathrm{~mm}\end{array}$ & $\begin{array}{l}\text { Linear-lanceolate, } 3.2-4.0 \times \\
0.6-1.1 \mathrm{~mm}\end{array}$ \\
\hline Color of corolla & Pale purple to bluish purple & White to red-purple & White to pale bluish \\
\hline Corolla size & c. $3.5 \mathrm{~cm}$ long & c. $4 \mathrm{~cm}$ long & c. $2.4 \mathrm{~cm}$ long \\
\hline Tube shape & Nearly tubular & Narrowly funnelform & Narrowly funneliform \\
\hline Lips of corolla & $\begin{array}{l}\text { Adaxial lip c. } 6 \mathrm{~mm} \text {; abaxial } \\
\text { lip c. } 8-9 \mathrm{~mm}\end{array}$ & $\begin{array}{l}\text { Adaxial lip c. } 8 \mathrm{~mm} \text {, } \\
\text { abaxial lip c. } 1.2 \mathrm{~cm}\end{array}$ & $\begin{array}{l}\text { Adaxial lip c. } 4 \mathrm{~mm} \text {, abaxial } \\
\text { lip c. } 9 \mathrm{~mm}\end{array}$ \\
\hline Filaments & $0.9-1.1 \mathrm{~cm}$ long & c. $1.4 \mathrm{~cm}$ long & c. $1 \mathrm{~cm}$ long \\
\hline Anthers & Glabrous & Bearded & Bearded \\
\hline Staminodes & 3 & 3 & 2 \\
\hline Flowering time & November to December & September to December & April \\
\hline
\end{tabular}

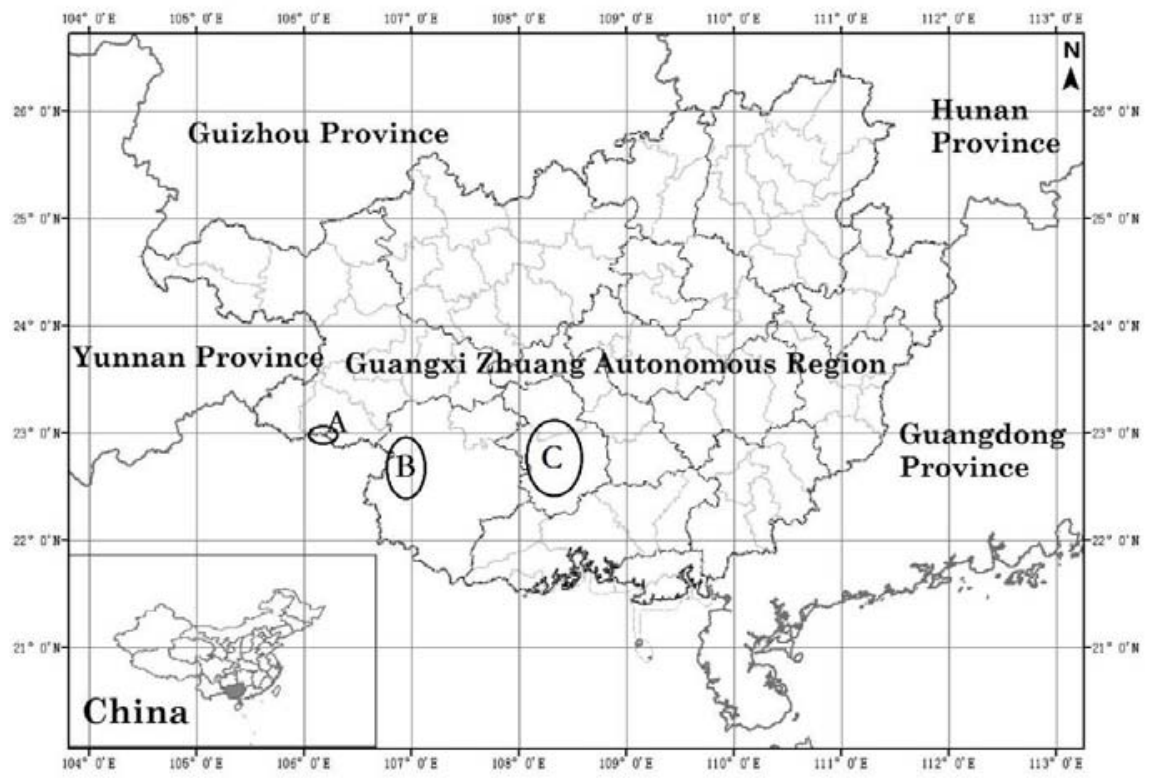

Fig. 3 Distribution of Primulina crassirhizoma F. Wen, Bo Zhao \& Xin Hong sp. nov. (A) and its related species, P. longgangensis (W.T. Wang) Y.Z. Wang (B) and P. linearifolia (W.T. Wang) Y.Z. Wang (C) in China. 
Additional specimens examined: CHINA. Guangxi Zhuangzu Autonomous Region: Jingxi County, Pingan Town, Guobu village, on the precipice of limestone hills, $23^{\circ} 00^{\prime} 02.20^{\prime \prime} \mathrm{N}$, $106^{\circ} 12^{\prime} 13.35^{\prime \prime}$ E, 1010 m, 02 November, 2010, Zhang Li-Bing, He Hai \& Wang Yu 5543 (CTC, MO, CDBI); Pingan Town, Longjin village, similar habitat, $22^{\circ} 59^{\prime} 29.89^{\prime \prime} \mathrm{N}, 106^{\circ} 11^{\prime} 00.91^{\prime \prime} \mathrm{E}, 980$ m, 2 November 2010, Zhang Li-Bing, He Hai \& Wang Yu 5517 (CTC, MO, CDBI).

\section{Acknowledgements}

The authors are grateful to Prof. Fa-Nan Wei for checking the Latin diagnosis, Prof. Xin-Hu Guo for checking the specimens and reviewing the description of this new species, and Mr. Qi Wei for drawings. This study was supported by Key Foundation of Education Department of Anhui Province (KJ2011A129), Provincial Key Laboratory of Biotic Environment and Ecological Safety in Anhui (2004sys003), Science Research Foundation of Guangxi Institute of Botany (Guizhiye11003), Director Fund project of Guangxi Key Laboratory of Functional Phytochemicals Research and Utilization (ZRJJ2012-9), the Guangxi Natural Science Foundation (2011GXNSFB018050), Science Research Foundation of Guangxi Academy of Sciences (no. 12YJ25ZW013) and West Light Foundation of the Chinese Academy of Sciences.

\section{References}

Li, Z.Y. and Wang, Y.Z. 2004. Primulina, Chirita and Chiritopsis. In: Li, Z.Y. and Wang, Y.Z. (Eds), Plants of Gesneriaceae in China. Henan Sci. \& Technol. Publ. House, Zhengzhou, pp. 170-282.

Wang, W.T. and Huang, X.C. 1982. A new species of Chirita (Gesneriaceae). Guihaia 2(4): 171-174.

Wang, W.T. and Pan, K.Y. 1982. Notulae de Gesneriaceis Sinensibus III. Bull. Bot. Res. 2(2): 121-152.

Wang, W.T., Pan, K.Y. and Li, Z.Y. 1990. Gesneriaceae. In: Wang, W.T. (Ed.), Flora Reipublicae Popularis Sinicae 69. Science Press, Beijing, pp. 125-581.

Wang W.T., Pan, K.Y. and Li, Z.Y. 1998. Gesneriaceae. In: Wu, Z.Y. and Raven, P.H. (Eds), Flora of China Vol. 18. Science Press, Beijing \& Missouri Bot. Garden Press, St. Louis, 322 pp.

Wang, Y.Z., Mao, R.B., Liu, Y., Li, J.M., Dong, Y., Li, Z.Y. and Smith, J.F. 2011. Phylogenetic reconstruction of Chirita and allies (Gesneriaceae) with taxonomic treatments. J. System. Evol. 49: 50-64.

Weber, A., Middleton, D.J., Forrest, A., Kiew, R., Lim, C.L., Rafidah, A.R., Sontag, S., Triboun, P., Wei, Y.G., Yao, T.L. and Möller, M. 2011. Molecular systematics and remodelling of Chirita and associated genera (Gesneriaceae). Taxon. 60: 767-790.

Wei, Y.G., Wen, F., Möller, M., Monro, A., Zhang, Q., Gao, Q., Mou, H.F., Zhong, S.H. and Cui, C. 2010. Gesneriaceae of South China. Guangxi Science and Technology Publishing House, Nanning, 777 pp. (Chinese and English).

Wen, F., Li, W.L., Zhao, B., Liang G.Y. and Wei, Y.G. 2012a. Primulina purpurea F. Wen, B. Zhao and Y.G Wei (Gesneriaceae), A New Species from China. Bangladesh J. Plant Taxon. 19(2): 167-172.

Wen, F., Qin, G.L., Wei, Y.G., Liang, G.Y. and Gao, B. 2012b. Primulina hochiensis var. rosulata (Gesneriaceae) - a new variety at an entrance of a limestone cave from Guangxi, China. Phytotaxa 54: 37 42.

Wen, F., Xi, S.L., Wang, Y., Xiang, M.S. and Fu, L.F. 2012c. Primulina fengshanensis (Gesneriaceae), a new species from Guangxi, China. Ann. Bot. Fennici 49: 103-106.

Xu, W.B., Zhang, Q., Wen, F., Liao, W.B., Pan, B., Chang, H. and Chung, K.F. 2012. Nine new combinations and one new name of Primulina (Gesneriaceae) from South China. Phytotaxa 64: 1-8. 